DOI 10.37882/2223-2974.2020.09.18

\title{
К ВОПРОСУ О ЦЕЛЯХ УЧАСТИЯ ПРОКУРОРА В СУДАХ ОБЩЕЙ ЮРИСДИКЦИИ
}

\section{ON THE QUESTION OF THE PURPOSE OF PARTICIPATION OF THE PROSECUTOR IN COURTS OF GENERAL JURISDICTION \\ O. Nikonorova}

Summary: The article deals with certain issues of the goals of participation of the Prosecutor in civil proceedings, the history of the formation of prosecutors in courts, analyzes the forms of his participation to protect the rights and legitimate interests of citizens and the state, as well as such a legal position on the case as giving an opinion in order to Express the position of legality of the state body. In the course of the generalization of norms of the Civil procedural code of the Russian Federation, Federal law «0n the procuracy of the Russian Federation» the author highlights the contradictions between the GPK of the Russian Federation and the Federal law «0n the procuracy of the Russian Federation», the conclusion about the need to address gaps in the existing legislation by introducing amendments to certain legislative acts.

Keywords: civil proceedings, Prosecutor, goals of participation of the Prosecutor in civil proceedings, forms of participation of the Prosecutor in the case, protection of the rights of citizens, legal entities, state and municipal entities, giving an opinion on the case.
И стория развития законодательства о суде и прокуратуре показывает, что эти два государственных органа всегда были связаны между собой.

Именным Указом Петра І от 18.01.1722 были учреждены прокуроры в первую очередь именно при судах.

В течение первых почти полутора веков своей истории прокуратура, созданная в России Петром I, (до судебных реформ 60-х годов XIX века) была преимущественно органом надзора за администрацией на местах, а судебная обвинительная или исковая деятельность составляла лишь одно из частных дополнений к функции надзора, едва намеченное в законе, слабое и неэффективное на практике.

Утверждение в 1862 г. царем «Основных положений преобразования судебной части в России». В соответствии с этим актом российская прокуратура должна была полностью преобразиться. Она освобождалась от функций общего надзора с его пресловутым просмотром решений губернских учреждений. Ее надзор ограничивался исключительно судебной сферой.

\author{
Никонорова Ольга Евгеньевна \\ старший прокурор, Генеральная прокуратура РФ; \\ аспирант, Университет прокуратуры \\ Российской Федерации \\ kaolgaeva@mail.ru
}

Аннотация: В статье рассматриваются отдельные вопросы целей участия прокурора в гражданском судопроизводстве, история становления прокуроров при судах, анализируются формы его участия для защиты прав и законных интересов граждан и государства, а также такая правовая позиция по делу как дача заключения в целях выражения позиции законности государственного органа. В ходе обобщения норм Гражданского процессуального кодекса РФ, Федерального закона «0 прокуратуре Российской Федерации» автором отмечаются противоречия между ГПК РФ и Федеральным законом «0 прокуратуре Российской Федерации», делается вывод о необходимости устранения пробелов в действующем законодательстве путем внесения изменений в отдельные законодательные акты.

Ключевые слова: гражданское судопроизводство, прокурор, цели участия прокурора в гражданском судопроизводстве, формы участия прокурора в деле, защита прав граждан, юридических лиц, государственных и муниципальных образований, дача заключения по делу.

В гражданском процессе круг дел, в которых должен был принимать участие прокурор, был ограничен делами казны, лиц, состоящих под опекой, безвестно отсутствующих и некоторых других, нуждавшихся, по мнению законодателя, в особой защите со стороны закона[16].

Обращение к истории развития законодательства о суде и прокуратуре показывает, что прокуратура всегда была связана с гражданским судом. При этом цель участия прокурора в гражданском процессе всегда носила ярко выраженный публичный характер, поскольку прокурор, участвующий в процессе, являлся представителем государственной власти.

Поэтому одной из наиболее дискуссионных тем до сих пор является тема необходимости участия прокурора в делах гражданского судопроизводства. Оспаривается как необходимость участия прокурора в делах гражданского производства, так и случаи, когда такая необходимость возникает [9, 7]. Приведем лишь некоторые аргументы, которые выдвигают противники участия прокурора в гражданском судопроизводстве. Так, например, Арестова О.Н. в комментариях к арбитражному процессуальному кодексу пишет о: «нарушении прин- 
ципа состязательности и равноправия в гражданском судопроизводстве»[6], о том, что необходимо ограничивать государственное вмешательство в частные дела граждан, а участие прокурора в гражданском судопроизводстве именно этим и является, по мнению этих авторов [15]. Также, отдельные авторы указывают на то, что участие в гражданском судопроизводстве прокурора отрицательно сказывается на процессуальной активности самих сторон, приводит к тому, что стороны начинают полагаться на помощь прокурора и не пользуются полномочиями представленными им процессуальными кодексами [17]. С другой стороны, есть и обратные мнения, так, например, некоторые авторы считают, что полномочия прокурора в гражданском процессуальном праве необоснованно урезаны [8].

Bсе это говорит, что тема целей участия прокурора в судах общей юрисдикции является востребованной и актуальной. Разберем законодательное закрепление целей участия прокурора в гражданском судопроизводстве. Данные цели вытекают из положений ч. 1 и 3 ст. 45 ГПК РФ [1], а именно, прокурор выступает в гражданском судопроизводстве с двумя целями, а именно, защита интересов отдельных граждан, перечень которых закреплен в ч. 1 ст. 45 ГПК РФ или группы граждан (например, потребители), вторая цель участия прокурора в гражданском судопроизводстве вытекает из ч. 3 ст. 45 ГПК РФ - дача заключения по отдельным категориям дел, например, по делам о выселении, о восстановлении на работе, о возмещении вреда, причиненного жизни или здоровью, в иных случаях предусмотренных законом. Следует отметить, что данные цели прямо не закреплены в ГПК РФ, а вытекают из положений ст. 45 ГПК РФ, которая раскрывает формы участия прокурора в гражданском судопроизводстве.

Разберем более подробно указанные цели. Первая цель вытекает из ч. 1 ст. 45 ГПК РФ - защита прав, свобод и законных интересов граждан, неопределенного круга лиц или интересов Российской Федерации, субъектов Российской Федерации, муниципальных образований. Заявление в защиту граждан подается в строго оговоренных законом случаях, а именно, в случаях указанных в ч. 1 ст. 45 ГПК РФ, как в порядке искового производства (исковые заявления), так и по делам, рассматриваемым в порядке приказного и особого производства, а также возникающим из публичных правоотношений. В таких случаях прокурор является воляизъявителем и инициатором возбуждения судом дела о защите прав, свобод и законных интересов граждан, именно он определяет, обращаться ему в суд с заявлением или нет.

Прокурор наделяется процессуальными правами и обязанностями истца, занимая положение истца в процессуальном смысле, такое процессуальное положение имеет и особенности. В частности, прокурор не может быть судебным представителем стороны или третьего лица, к прокурору не может быть предъявлен встречный иск, у него отсутствует право на заключение мирового соглашения, также он освобождается от уплаты государственной пошлины.

В случае предъявления иска прокурор, предъявивший его, имеет ряд обязанностей. Так он должен: ссылаться на закон или иной нормативный акт, подлежащий применению, указывать, в чем конкретно заключаются интересы Российской Федерации, субъектов Федерации, муниципальных образований или неопределенного круга лиц; указывать, какое право нарушено. В случае обращения прокурора в защиту законных интересов гражданина в иске должно содержаться обоснование невозможности предъявления иска самим гражданином либо указание на обращение гражданина к прокурору.

Справедливо, по мнению автора, суждение М.С. Шакарян о том, что «при предъявлении иска прокурор занимает в деле положение истца, но только в процессуальном смысле» [13].

Проиллюстрируем указанные случаи материалами правоприменительной практики. Так, например, Брянский природоохранный прокурор в защиту прав и законных интересов неопределенного круга лиц обратился в суд с иском к администрации района Брянской области, МКП «Коммунальник» о возмещении вреда, причиненного окружающей среде в результате эксплуатации предприятием земельного участка, предоставленного под свалку без выполнения требований санитарного и природоохранного законодательства.

Поскольку такими действиями ответчиками почвам как объекту охраны окружающей среды причинен вред, прокурор просил взыскать с них в бюджет РФ в счет возмещения вреда компенсацию в размере 55 731333,33 рублей. Судом исковые требования прокурора удовлетворены в полном объеме [3].

По иску Урюпинской межрайонной прокуратуры Волгоградской области, действующей в интересах Российской Федерации в лице МИФНС России Волгоградской области, судом с гражданина К. взыскано в счет возмещения ущерба от преступления, предусмотренного ч. 1 ст.199 УК РФ, денежные средства в сумме 11761363 руб. 63 коп.

В обоснование заявленных требований прокурор указал, что К. являясь руководителем организации уклонялся от уплаты в бюджет Российской Федерации НДС в общей сумме 11761363 руб.63 коп. Уголовное дело в отношении ответчика прекращено на основании п. 3 ч. 1 ст. 24 УПК РФ в связи с истечением давности уголовного преследования. Данное постановление вступило в законную силу [4]. 
Если статус прокурора, инициирующего гражданский процесс, более или менее определен, то этого нельзя сказать в отношении вступления прокурора в процесс для дачи заключения, в то время такая форма участи имеет процессуально важное значение. Часть 3 ст. 45 ГПК РФ не раскрывает цель дачи данного заключения, указываются лишь случаи, когда прокурор дает такие заключения.

Автор отмечает, что вступление прокурора в гражданское судопроизводство в порядке ч. 3 ст. 45 ГПК РФ имеет свои нюансы. Прежде чем перейти к их изучению, необходимо сказать несколько слов о том, что представляет собой заключение прокурора как процессуальный документ. В обобщенном виде под заключением в гражданском судопроизводстве предлагается понимать форму выражения мнения специального органа (прокурора, органов государственной власти, местного самоуправления) по конкретному гражданскому делу, содержащего государственно-властное веление, выраженное письменно (устно) и направленного на индивидуальное регулирование общественных отношений, имеющего рекомендательный характер для суда [14].

Законодателем установлен перечень дел, по которым в обязательном порядке требуется заключение прокурора, однако данные правоотношения регулируются кроме ГПК РФ еще и другими нормативно правовыми актами.

Например, согласно ГПК РФ: по делам, возникающим из публичных правоотношений (ст. 252, 260), по делам особого производства (ст. 273, 278, 284, 288, 304 ГПК РФ), по другим федеральным законам - о лишении родительских прав (ст. 70 СК РФ); о восстановлении в родительских правах (ст. 72 СК РФ); об ограничении родительских прав (ст. 73 СК РФ); от отмене усыновления ребенка (ст. 140 CК РФ).

В ст. 189 ГПК РФ закреплено, что «председательствующий предоставляет слово для заключения по делу прокурору», в какой форме - в устной или письменной дается такое заключение гражданское процессуальное законодательство не предусматривает.

Следует отличать заключение прокурора от его объяснений, как две разных процессуальных позиции, вытекающих из полномочий прокурора в судебной инстанции поскольку заключение не относиться к средствам доказывания в отличии от объяснений в которых прокурор доказывает обоснованность соответствующих требований и выступает до прения сторон.

Обратимся к научной литературе, в которой раскрывается цель указанного участия, так, например, Артебякина Н.А. пишет, что в данном случае: «Цель участия прокурора в подобных случаях - доведение до сведения суда и других участников гражданского судопроизводства мнения относительно рассматриваемого общественно значимого вопроса, выводов по существу разрешаемых судом требований» [7]. В.В. Ярков указывает, что, цель вступления прокурора с заключением в уже начатый процесс является защита государственных и общественных интересов, а также прав и законных интересов граждан [12]. Юдельсон К.С. указывает такую общую цель участия прокурора в гражданском судопроизводстве, как осуществление функции охраны закона и правопорядка [18].

Заключение прокурора по делу имеет и определенное доказательственное значение, поскольку прокурор в ходе подготовки данного заключения проводит определенную проверку материалов и документов, соответственно его заключение аргументировано и мотивированно. Такого мнения придерживается, например, М.К. Треушников [1 1] и В.В. Яроков [12]. Следует отметить, однако, что не все ученые придерживаются такого мнения. Противоположного мнения придерживается, например, А.Г. Григорьев [14], который пишет, что поскольку сведения о фактах присутствуют лишь в описательной части, а суть заключения содержится в выводах, то данное заключение не может иметь доказательственное значение.

Мы поддерживаем первую точку зрения, поскольку, как уже указывалось нами, в оде подготовки данного заключения прокурор проводит определенную доказательственную и аналитическую проверку и доводы заключения надлежащим образом аргументированы.

Таким образом, если подвести короткий итог рассматриваемым мнениям, можно сказать, что целью участия прокурора в гражданском судопроизводстве, в случае дачи заключения по делу, является доведения до суда позиции государственного органа призванного охранять законность и правопорядок. В идеале, эта позиция должна являться отражением законности и правопорядка.

Проиллюстрируем такое основание участия прокурора в гражданском судопроизводстве материалами правоприменительной практики. Так, например, по одному из дел прокуратура Октябрьского района г. Белгорода области дала заключение по гражданскому делу по иску о лишении родительских прав отца несовершеннолетнего ребенка, 2011 года рождения.

Установлено, что ответчик на протяжении самоустранился от воспитания своего ребенка, материально и морального не поддерживал, в связи с неисполнением обязательств по уплате алиментов он неоднократно привлекался к уголовной ответственности. 
Исходя из интересов несовершеннолетнего и принимая во внимание заключение органов опеки и попечительства, участвующий в деле прокурор дал заключение о целесообразности лишения ответчика родительских прав

\section{Судом исковые требования удовлетворены [5].}

Следует отметить, что существуют серьезные законодательные противоречия между ГПК РФ и Федеральным законом от 17 января 1992 г. N 2202-1 «О прокуратуре Российской Федерации» [2]. Указанный закон не содержит такую форму деятельности прокурора, которая предусмотрена в ч. 3 ст. 45 ГПК РФ - дача заключения по делу. Это безусловно свидетельствует о нарушении юридической техники поскольку Федеральный закон от 17 января 1992 г. N 2202-1 «О прокуратуре Российской Федерации» является базовым, ключевым законом в деятельности прокурора, то есть, он должен быть дополнен положениями о такой форме деятельности прокурора как дача заключения в гражданском судопроизводстве. Это возможно, например, путем дополнения ч. 3 ст. 35 Федерального закона от 17 января 1992 г. N 2202-1 «О прокуратуре Российской Федерации».

Прокурор участвует в рассмотрении дел судами, дает заключения по существу рассматриваемого дела в случаях, предусмотренных процессуальным законодательством Российской Федерации и другими федеральными законами.

Из всего вышерассмотренного, можно сделать вывод, что цели участия прокурора в гражданском судопроизводстве вытекают как из Федерального закона от 17 января 1992 г. N 2202-1 «О прокуратуре Российской Федерации», так и из ГПК РФ - это прежде всего задачи охраны закона и правопорядка, охрана нарушенных прав граждан, государственных и муниципальных образований, а также такая специфическая задача, как дачи заключения по делу, доведения до суда позиции государственного органа призванного охранять законность и правопорядок. В идеале, эта позиция должна являться отражением законности и правопорядка.

\section{ЛИТЕРАТУРА}

1. Гражданский процессуальный кодекс Российской Федерации от 14.11.2002 N 138-Ф3 (ред. от 24.04.2020) // Собрание законодательства РФ.- 2002. N 46.ст. 4532.

2. Федеральный закон от 17.01.1992 N 2202-1 (ред. от 06.02.2020) «0 прокуратуре Российской Федерации» // Собрание законодательства РФ.- $1995 .-$ N 47. Ст. 4472.

3. Дело № 2-77/2019 Брянского областного суда // https://oblsud--brj.sudrf.ru/modules.php?name=sud_delo\&srv_num=1\&name_ op=doc\&number=1998792\&delo_id=5\&new=5\&text_number=1\&case_id=1900892 (дата обращения: 20.08.20)

4. Решение по гражданскому делу Первого кассационного суда № 88-5461/2020 // https://1kas.sudrf.ru/modules.php?name=sud_delo\&srv_num=1\&name_ op $=$ doc\&number=3760972\&delo_id=2800001\&new=2800001\&text_number=1 (дата обращения: 20.08.20)

5. Дело Октябрьского района Белгородской области // http://oblsud.blg.sudrf.ru/modules.php?name=sdp2_cases (дата 0бращения: 20.08.20)

6. Арестова 0.Н. Комментарий к основным положениям Арбитражного процессуального кодекса РФ // Подготовлен для СПС «Консультант Плюс», 2011.

7. Артебякина Н.А. Дача заключения по делу как форма участия прокурора в гражданском судопроизводстве // Юрист. 2019. N 12.

8. Ахметзянов С.И., Лошкарев А.В. Участие прокурора в гражданском процессе // Международный журнал гуманитарных и естественных наук. 2020 . № 4-2.

9. Воробьев Т.Н. Цели участия прокурора в рассмотрении судом гражданских дел // Современное право. 2017. N 5.

10. Гражданский процесс: Учебник / Под ред. В.В. Яркова. М.: Инфотропик Медиа, 2012.

11. Гражданский процесс: Учебник / Под ред. М.К. Треушникова. М.: Статут, 2014.

12. Гражданский процесс: Учебник для студентов вузов / Под ред. В.В. Яркова. М.: Волтерс Клувер, 2006.

13. Гражданское процессуальное право. Учебник / Под ред. М.С. Шакарян. М. 2004.

14. Григорьев А.Н. Заключения как формы выражения мнений отдельных участников гражданского судопроизводства: автореф. дис. ... канд. юрид. наук. Саратов, 2011.

15. Жилин Г.А. Цели гражданского судопроизводства и их реализация в суде первой инстанции. М., 2000.

16. Казанцев С.М. Прокуратура Российской империи: историко-правовое исследование: автореф. дис. канд. юрид. наук. СПб., 2003.

17. Плешаков А.Г. Диспозитивное начало в сфере гражданской юрисдикции: проблемы теории и практики. М., 2002.

18. Юдельсон К.С. Советский гражданский процесс. М., 1956.

(c) Никонорова Ольга Евгеньевна (kaolgaeva@mail.ru). 